\title{
Assessment of On-site sanitation system on local groundwater regime in an alluvial aquifer
}

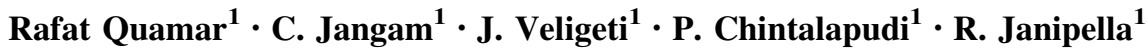

Received: 4 November 2016/Accepted: 15 June 2017/Published online: 24 June 2017

(c) The Author(s) 2017. This article is an open access publication

\begin{abstract}
The present study is an attempt to study the impact of the On-site sanitation system on the groundwater sources in its vicinity. The study has been undertaken in the Agra city of Yamuna sub-basin. In this context, sampling sites (3 nos) namely Pandav Nagar, Ayodhya Kunj and Laxmi Nagar were selected for sampling. The groundwater samples were analyzed for major cations, anions and faecal coliform. Critical parameters namely chloride, nitrate and Faecal coliform were considered to assess the impact of the On-site sanitation systems. The analytical results shown that except for chloride, most of the samples exceeded the Bureau of Indian Standard limits for drinking water for all the other analyzed parameters, i.e., nitrate and faecal coliform in the first two sites. In Laxmi Nagar, except for faecal coliform, all the samples are below the BIS limits. In all the three sites, faecal coliform was found in majority of the samples. A comparison of present study indicates that the contamination of groundwater in alluvial setting is less as compared to hard rock where On-site sanitation systems have been implemented.
\end{abstract}

Keywords On-site sanitation - Seasonal variation . Groundwater $\cdot$ Nitrate $\cdot$ Faecal coliform

Rafat Quamar

rafatquamar2010@gmail.com

1 National Environmental Engineering Research Institute, Nehru Marg, Nagpur 440020, India

\section{Introduction}

On a global scale, fresh water constitutes approximately $2.5 \%$ on earth and groundwater constitutes only $0.76 \%$ of fresh water. Hence, it is essential to protect the fresh groundwater as per the quality and quantity points of view. In the last decade, the growing population has increased the stress on groundwater resources due to which the quality has degraded due to anthropogenic as well as geogenic factors. The contamination of groundwater in many parts of India is caused by the disposal of domestic waste (Pujari et al. 2007, 2012; Jangam et al. 2015). The anthropogenic factors are, namely, the disposal of untreated industrial and municipal wastewater, application of fertilizers and pesticides in the agricultural fields, leakage from underground storage tanks, underground pipelines, and plumes generation from landfill site and septic tank effluents. The problem assumes more importance when proper safeguards are not in place during the disposal of waste. The groundwater pollution caused by On-site sanitation was a major concern in many urban and peri-urban areas when organized sewerage is lacking and where the drinking water requirements are met from groundwater sources. The contamination is likely to take place in the event of a pathway existing between a source, i.e., On-site sanitation system and a receptor, i.e., groundwater source. The growing population has led to adopt the On-site sanitation system as compared to conventional sewerage. The On-site sanitation system poses a significant adverse impact on the groundwater quality in the long run. It assumes more importance when the geological settings favor the migration of contaminants. The problem becomes alarming when the groundwater table is shallow. The groundwater quality studies were reported by numerous authors (NEERI 2005; Pujari et al. 2007, 2012; Lu et al. 2008; Jangam et al. 2015) pertaining 


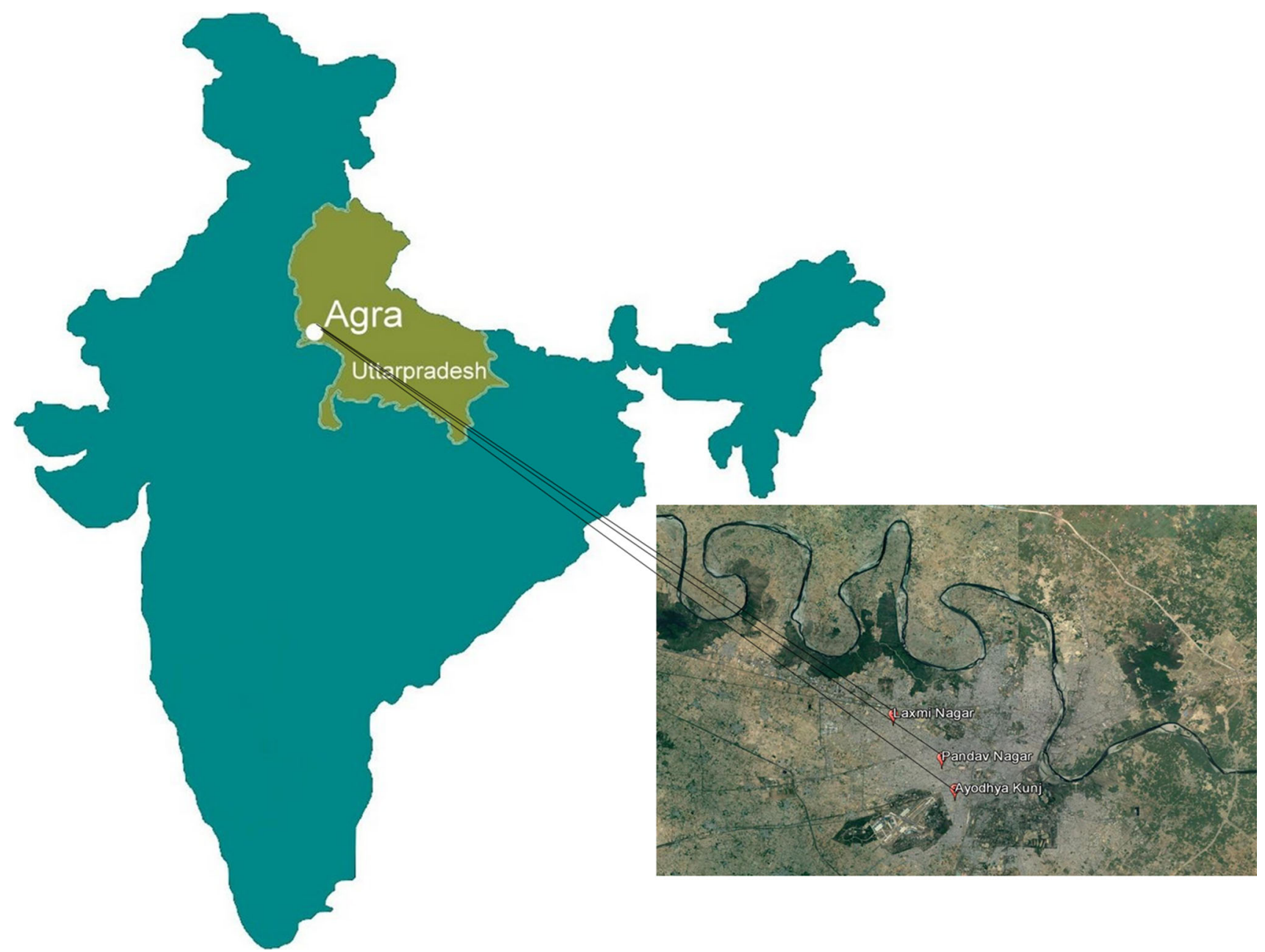

Fig. 1 Schematic map (not to scale) of India with study area (Agra city, Uttar Pradesh, India)

to the impact of septic tanks. Pujari et al. (2007) found that the increased concentration of nitrate and bacteria in groundwater near On-site sanitation system and showing the impact on groundwater quality.

The geohydrological issues, i.e., water table, soil characteristics and separation between the On-site sanitation system and groundwater source are key parameters affecting groundwater contamination (Lawrence et al. 2001). Dzwairo et al. (2006) clarified through pit latrine studies at Zimbabwe that the groundwater quality parameters, mainly total coliforms, faecal coliforms and nitrate were affected by the pit latrine. The studies on microbial movement near On-site sanitation systems show that the increased concentration of total and faecal coliform in period of monsoon in saturated condition of sandy soils and less in clay soils (Banerjee 2011). Similar study carried out in India by Pujari et al. (2012), Jangam et al. (2015) indicated that the contamination level in alluvial terrain in Kolkata and Lucknow was negligible as compared to the hard rock terrain in Indore in India. The National
Environmental Engineering Research Institute, Nagpur conducted study on impact of On-site sanitation on groundwater in selected cities in India and the study concludes that geological setting is one of the key parameters in groundwater contamination. The groundwater pollution due to On-site sanitation system relates primarily to unconfined and to semi-confined aquifers. If groundwater supplies are drawn from deep and confined aquifers, Onsite sanitation does not pose a significant hazard (NEERI 2005).

The present work aims to study the impact of On-site sanitation system on groundwater sources in quaternary sediments (sand, silt, clay and canker) in Agra city in India (Fig. 1) which is located on the bank of Yamuna River. Critical parameters namely chloride, nitrate and faecal coliforms (Lawrence et al. 2001; Pujari et al. 2007, 2012; Jangam et al. 2015) have been considered to study the impact of On-site sanitation systems. The study was carried out in pre-monsoon (May 2002) and post-monsoon (November 2002) seasons to find out the seasonal 


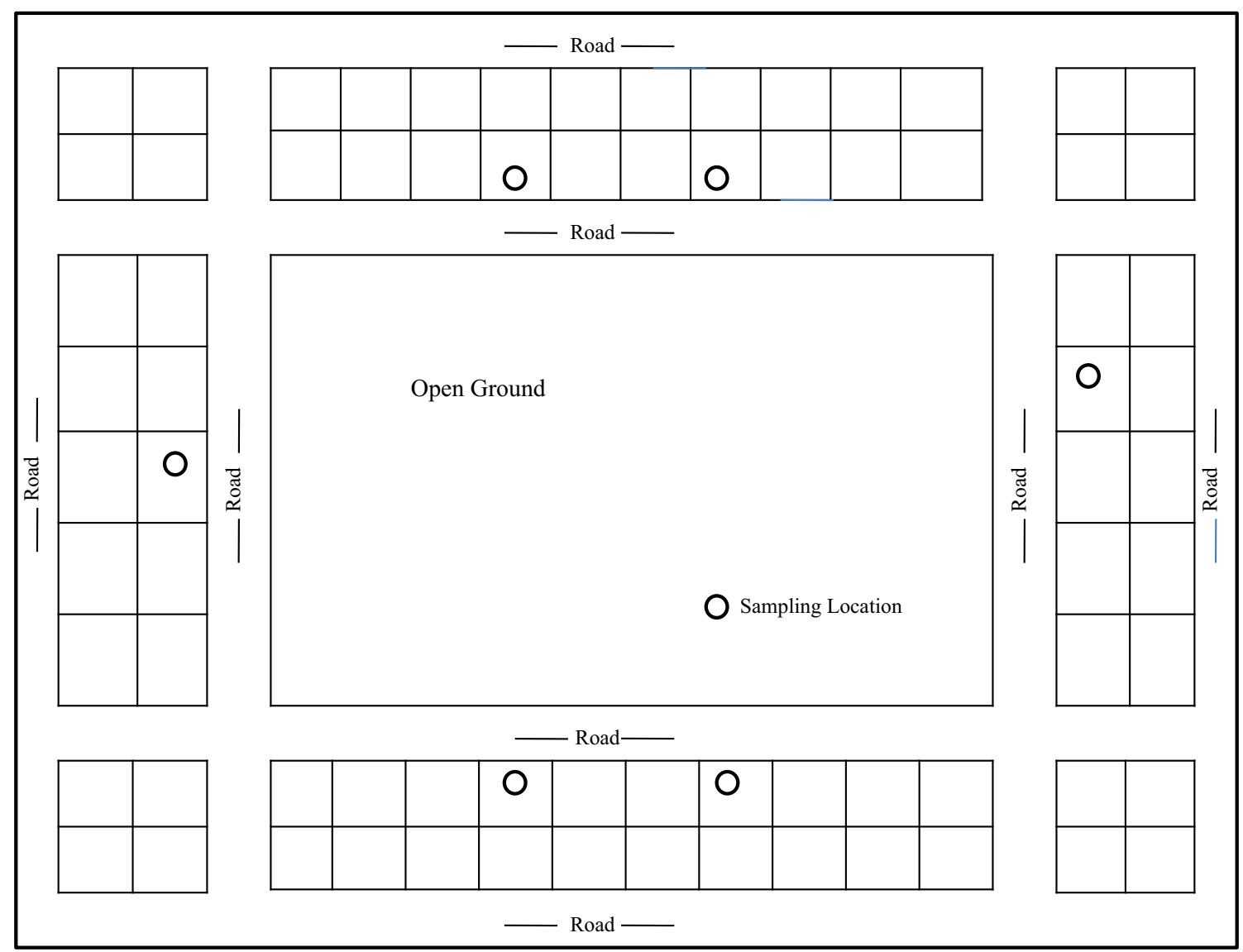

Fig. 2 Schematic map (not to scale) of sampling locations in Pandav Nagar, Agra

variations in concentration of contaminants in groundwater. The study was focused on groundwater quality which was affected by the On-site sanitation system.

\section{Study area}

Agra city is located at latitude $\mathrm{N} 27^{\circ} 10^{\prime}$ and Longitude E $78^{\circ} 03^{\prime}$ in western part of Uttar Pradesh and northern part of India (Fig. 1) covering an area of $188.4 \mathrm{~km}^{2}$. The city has a population of 1,567,709 as per the 2011 census (censusindia.gov.in). The maximum and minimum temperatures of Agra city in summer are 45 and $21.9^{\circ} \mathrm{C}$, respectively, whereas in winter, the maximum and minimum temperatures are 31.7 and $4.2{ }^{\circ} \mathrm{C}$ (agra.nic.in), respectively. The present area annual rainfall is $687.2 \mathrm{~mm}$ (GWYB 2014-2015) through the southwest monsoon.

Physiographically, the city is situated in the IndoGangetic plains (Yamuna sub-basin). It is mainly covered by quaternary sediments constituting an admixture of sand, silt, clay and canker. The aquifers are unconfined to semiconfined type. The city has partial sewerage coverage and On-site sanitation is the preferred mode in the unsewered areas and the city has limited sewer connection. Most of the areas have septic tanks.

\section{Methodology}

As the objective is to assess the impact of the On-site sanitation systems on the groundwater sources, sampling sites were chosen which did not have centralized sewerage facility and groundwater sources were present in the vicinity of the On-site sanitation systems. Accordingly, groundwater sampling locations (27 nos.) were selected based on the existing field conditions, i.e., absence of sewerage coverage and where the drinking water is directly tapped from groundwater using jet pumps (bore wells). The selected sites have only groundwater sources in the vicinity of the On-site sanitation systems. The sites selected in premonsoon and post-monsoon are namely Pandav Nagar (Fig. 2), Ayodhya Kunj (Fig. 3) and Laxmi Nagar (Fig. 4). The depth to water level varied in the range $10-15 \mathrm{~m}$ in pre-monsoon and $8-12 \mathrm{~m}$ in the post-monsoon seasons. Pandav Nagar is sewered locality having jet pumps for 


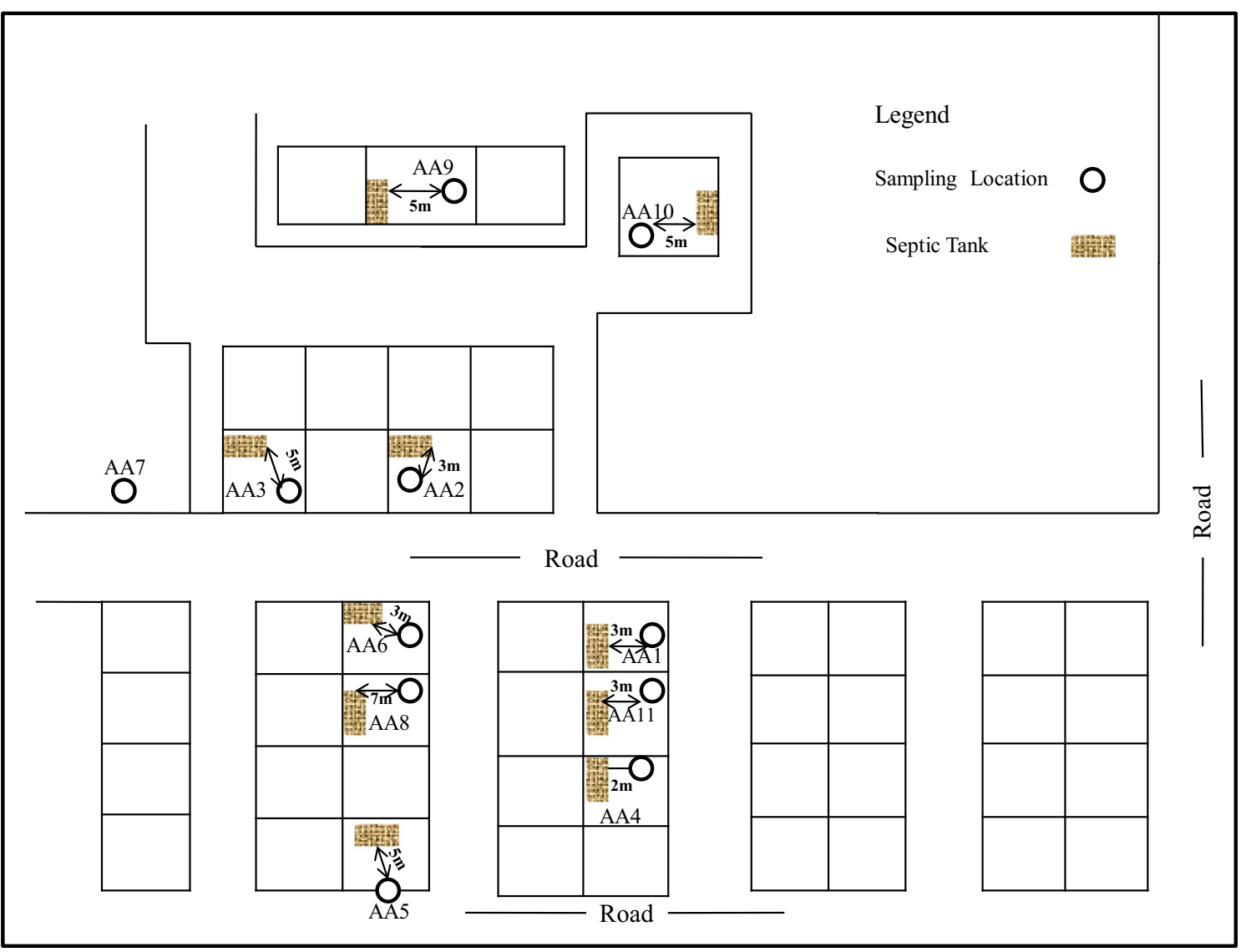

Fig. 3 Schematic map (not to scale) of sampling locations in Ayodhya Kunj, Agra

extraction of groundwater in the individual houses. The locality is well maintained and away from sources like solid disposal waste sites. In all the three sites mentioned above, the sampling locations selected are well scattered around the public toilets.

The sampling has been undertaken by the grab sampling approach. As far as bacteriological parameters are concerned, they were collected in glass bottles of $300 \mathrm{~mL}$. The bottles were thoroughly cleaned and sterilized before sampling. The bacteriological samples were carried to the laboratory in freezing condition $\left(4^{\circ} \mathrm{C}\right)$. Parameters viz. $\mathrm{pH}$, $\mathrm{EC}$ and temperature, were measured at the site with the help of portable sensors (Eutech make). Suspended particles were filtered by filter paper (Whatman make: no. 4) before analysis. The physicochemical parameters were analyzed by the standard protocols (American Public Health Association (APHA) 1998). The $\mathrm{NO}_{3}$ was carried out with the help of UV-Visible spectrophotometer 118 (Make: Systronic). Membrane filter technique (APHA 1998) has been followed for bacteriological analysis. The processed sample is kept in incubator to maintain at $45.5^{\circ} \mathrm{C}$ for $24 \mathrm{~h}$. Colony formations are done by using $50 \mathrm{~mm}$ sample and the bacterial count is in colony forming unit (CFU/100 mL).
A questionnaire survey was undertaken to study the presence of any water-borne disease in the area and its relation vis-à-vis the On-site sanitation systems. The residents dependent on the groundwater source were asked about the prevalence of any water-borne disease like jaundice and cholera in the area.

\section{Results and discussion}

There are various factors upon which groundwater contamination depends. Broadly, the factors are local hydrogeological characteristics like depth to water table, porosity and permeability of underlying strata, confined and unconfined rock types. As far as the anthropogenic contamination, i.e., from On-site sanitation system is concerned, the parameters affected will be namely, chloride, nitrate and faecal coliforms (Pujari et al. 2007, 2012; Jangam et al. 2015). The rock composition will not affect parameters like chloride and nitrate. It is found that the quantity of nitrogen releases of $4 \mathrm{~kg} / \mathrm{year} /$ person (Lawrence et al. 2001) and it is also reported that chloride $4 \mathrm{~g} /$ day is released per person through urine, faces, and sweat. Microbiological organisms are significant effect 


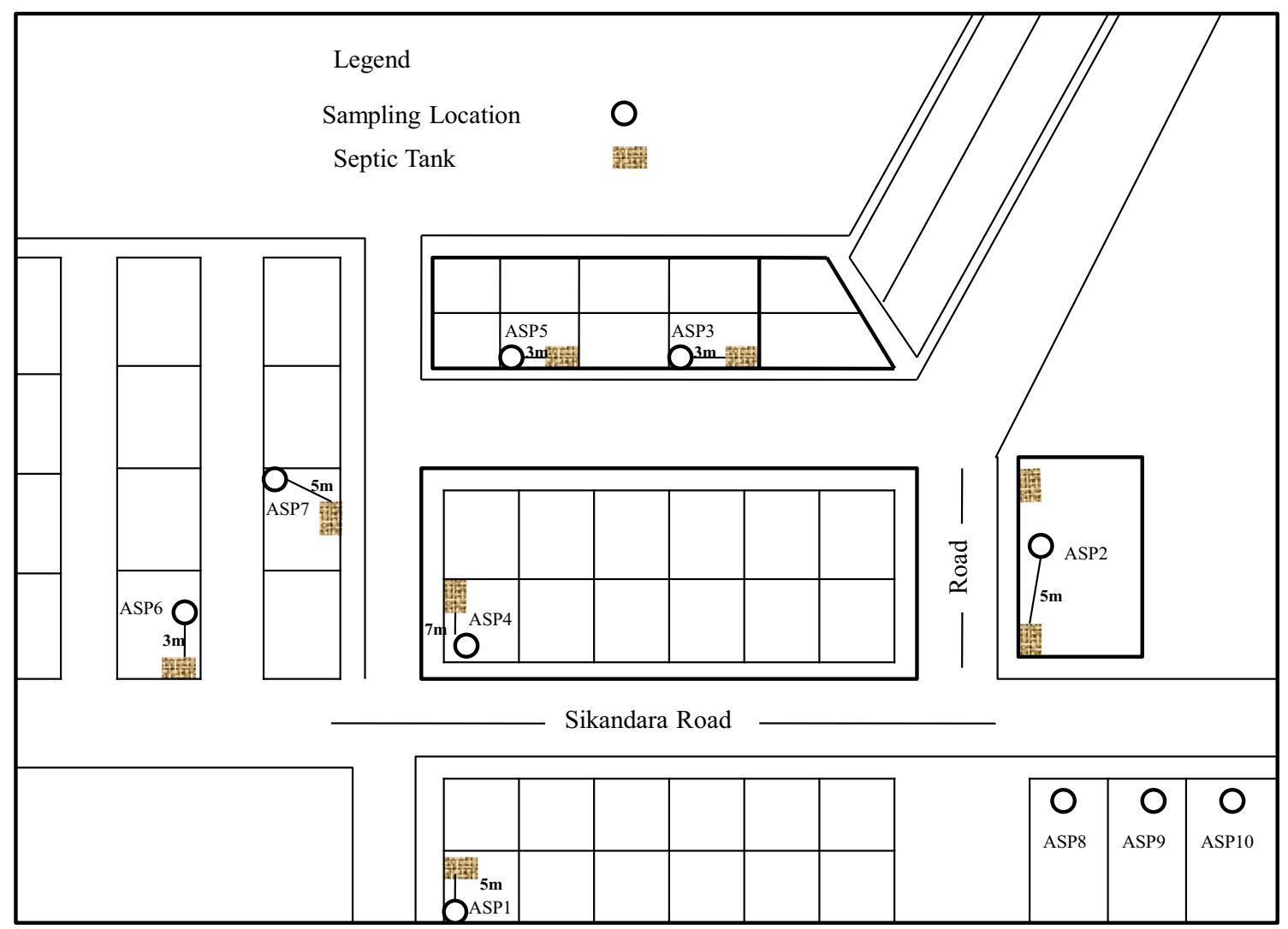

Fig. 4 Schematic map (not to scale) of sampling locations in Laxmi Nagar, Agra

Fig. 5 TDS concentration in samples BIS limit $(2000 \mathrm{mg} / \mathrm{L})$ collected from Pandav Nagar

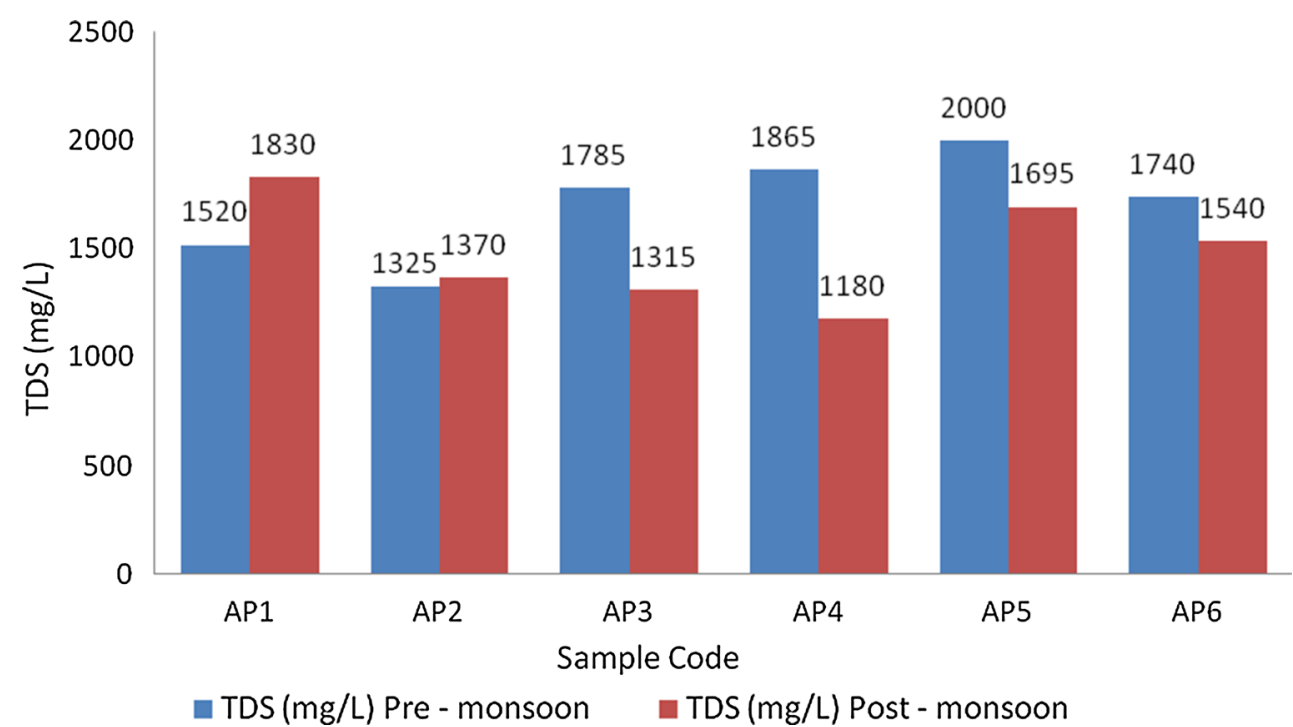

during their movements in the unsaturated zone (Lawrence et al. 2001). However, every attempt is made to figure out the sources of contamination based on the existing field conditions. Twenty-seven groundwater samples were collected at selected locations in pre-and post-monsoon seasons from Agra city. An attempt has been made to consider three samples as control sites for comparison. Samples namely, ASP8, ASP9 and ASP10 in Laxmi Nagar were collected as a control samples from locations away from On-site sanitation activity.

\section{Pandav Nagar (SITE I)}

Pandav Nagar is a sewered locality having jet pumps (bore wells) for extraction of groundwater in the individual houses. The locality is well maintained and away from 
Fig. 6 Chloride concentration in samples BIS limit (1000 mg/ L) collected from Pandav Nagar

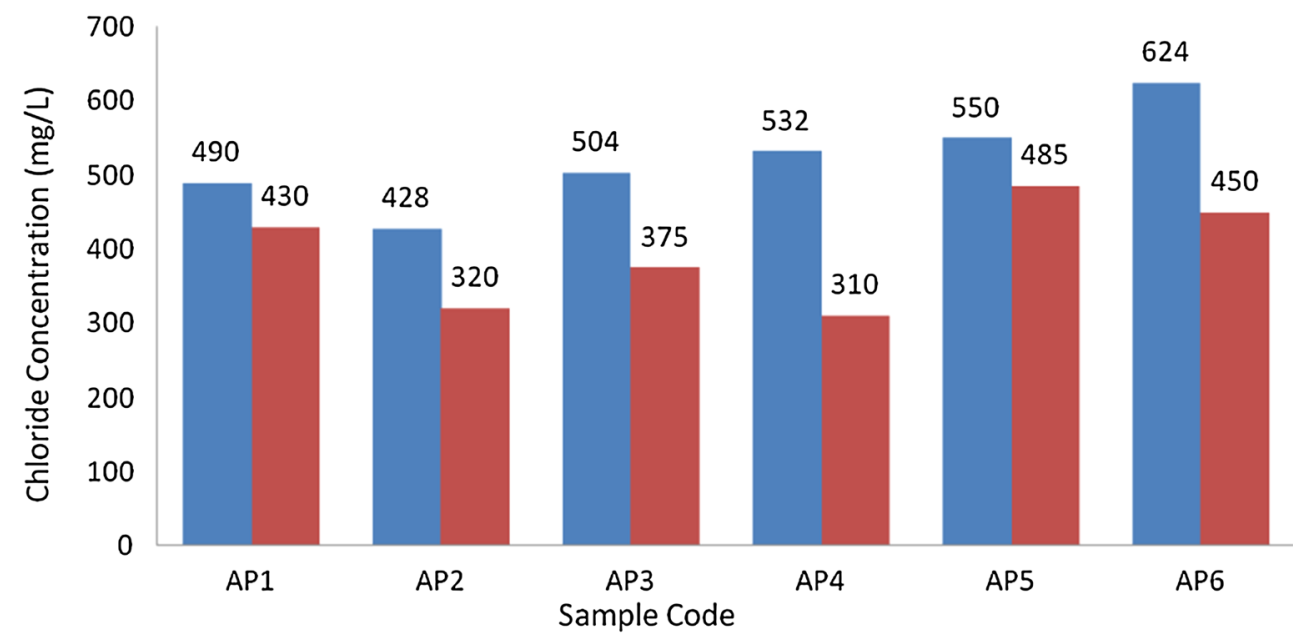

n Chloride as $\mathrm{Cl}(\mathrm{mg} / \mathrm{L})$ Pre - monsoon $\quad$ Chloride as $\mathrm{Cl}(\mathrm{mg} / \mathrm{L})$ Post - monsoon
Fig. 7 Nitrate concentration in samples BIS limit $(45 \mathrm{mg} / \mathrm{L})$ collected from Pandav Nagar

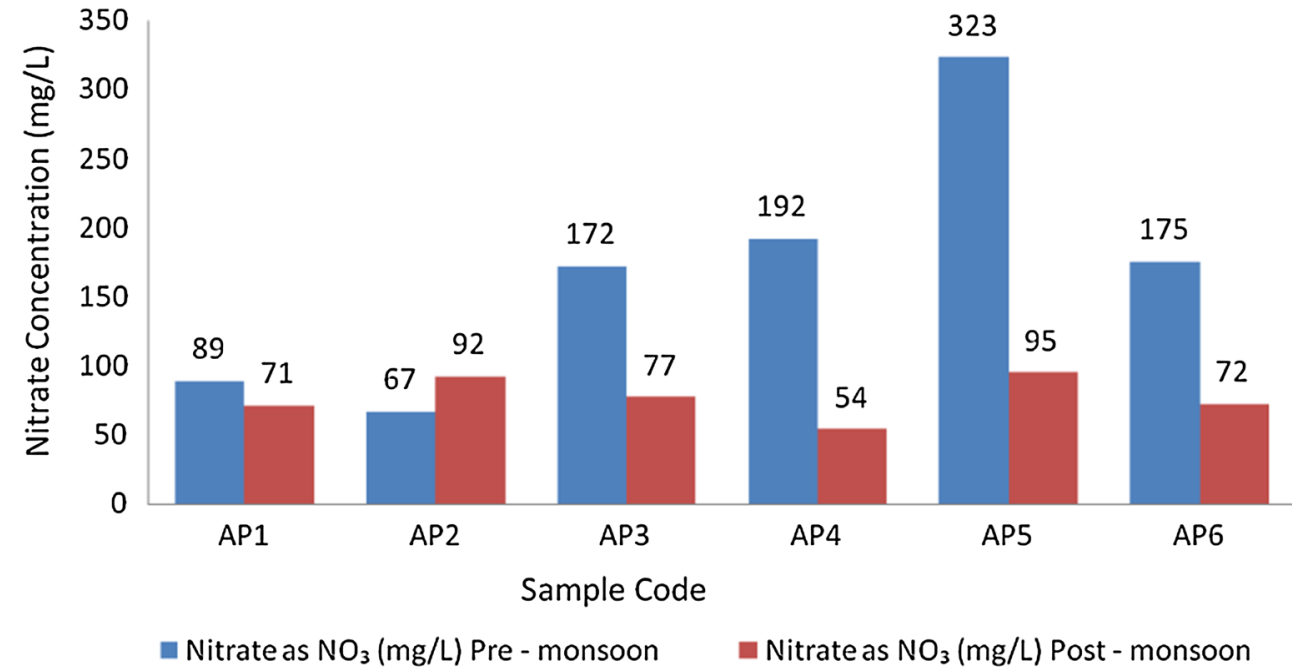

sources like solid waste disposal sites. The TDS concentration observed (Fig. 5) in pre-monsoon is 1325-2000 mg/ $\mathrm{L}$, which is high as compared to post-monsoon, i.e., 1180-1830 mg/L. At Pandav Nagar, it was observed that the concentration of chloride varied in the range $428-624 \mathrm{mg} / \mathrm{L}$ (pre-monsoon) to $310-485 \mathrm{mg} / \mathrm{L}$ (post-monsoon) and it is observed that all sample parameters (Fig. 6) were within the permissible limits of BIS (1991) and WHO (1993). It is evident that due to precipitation, the nitrate concentration varied in the range 67-323 and 54-92 $\mathrm{mg} / \mathrm{L}$ in pre-monsoon and post-monsoon, respectively (Fig. 7). All the samples are found to be more than BIS (1991) and WHO (1993) permissible limit for nitrate $(45 \mathrm{mg} / \mathrm{L})$ in pre-monsoon season and post-monsoon. In sample AP5, nitrate shows higher concentration with respect to other samples. The microbial analysis revealed that the concentration of faecal coliform in three samples were not detected in the pre-monsoon and three samples namely, AP2, AP3 and AP6 had concentration in the range 8-170 CFU/100 $\mathrm{ml}$. However, in post-monsoon it varied in the range $5-155 \mathrm{CFU} / 100 \mathrm{~mL}$ and was not detected in two samples, namely AP1 and AP5. The presence of high faecal coliforms in the bore well samples is indicative of pollution from On-site sanitation system (Fig. 8). The observation revealed that sewer connections can also contribute to contamination if it is not properly designed and malfunctioning of the sewer pipes can contribute to contamination of groundwater. Similar findings have been reported from Bhopal city in India (Pujari et al. 2007).

\section{Ayodhya Kunj (Site II)}

Eleven samples were collected in Ayodhya Kunj (Fig. 3) and analyzed. Ayodhya Kunj is unsewered with septic tanks located within every house hold and they were within a distance of 5-10 km from the jet pump. The TDS varied in the range $710-2140 \mathrm{mg} / \mathrm{L}$ in pre-monsoon and 825-2345 mg/L in post-monsoon (Fig. 9). It was observed 
Fig. 8 Faecal coliforms in samples collected from Pandav Nagar
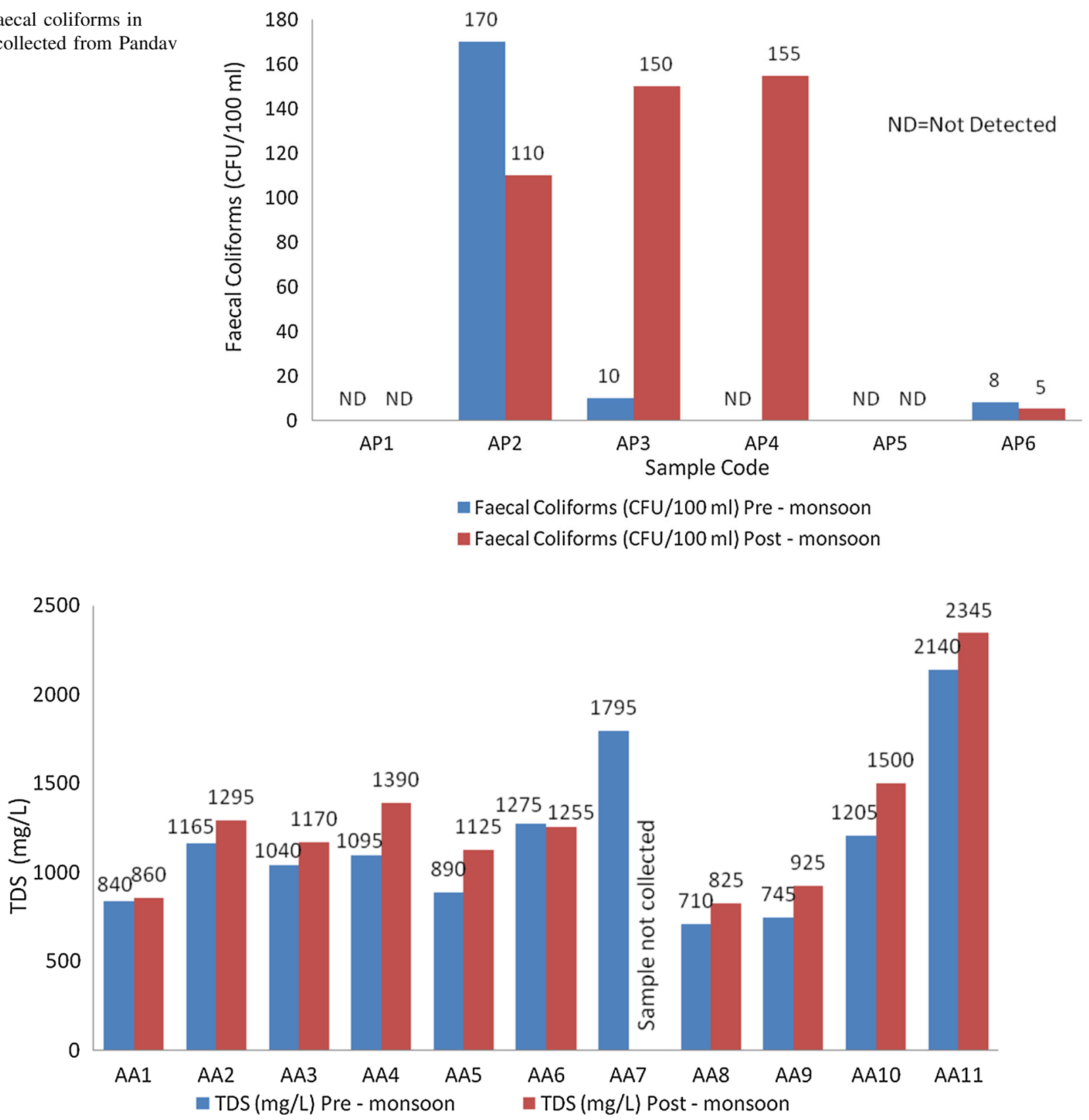

Fig. 9 TDS in samples BIS limit (2000 mg/L) collected from Ayodhya Kunj

that chloride concentration varied (Fig. 10) from 210 to $940 \mathrm{mg} / \mathrm{L}$ (pre-monsoon) to $186-800 \mathrm{mg} / \mathrm{L}$ (post-monsoon). All the chloride samples are found under the BIS (1991) and WHO (1993) limit of chloride (1000 mg/L. The range of nitrate concentration (Fig. 11) varied from 29-220 to $33-162 \mathrm{mg} / \mathrm{L}$ during pre-monsoon and post-monsoon, respectively. It seems that the variability of nitrate is complex as most of the samples showed elevated concentration in post-monsoon as compared to pre-monsoon. The depleted nitrate concentration (except AA3, AA4, AA10) in pre-monsoon can be attributed to the deepening of the sources leading to anaerobic conditions which induce the nitrogen gas by the conversion of nitrate. For nitrate concentration, most of the samples in both the seasons were above permissible limits of BIS (1991) and WHO (1993). Faecal coliform concentration (Fig. 12) varied in the range of $\mathrm{ND}$ to $50 \mathrm{CFU} / 100 \mathrm{~mL}$ (pre-monsoon) and ND$40 \mathrm{CFU} / 100 \mathrm{~mL}$ (post-monsoon).

\section{Laxmi Nagar (Site III)}

Seven samples were collected from Laxmi Nagar locality (Fig. 4). Besides, three samples (ASP8, ASP9, ASP10) were collected from the fringe, with the purpose of serving as 


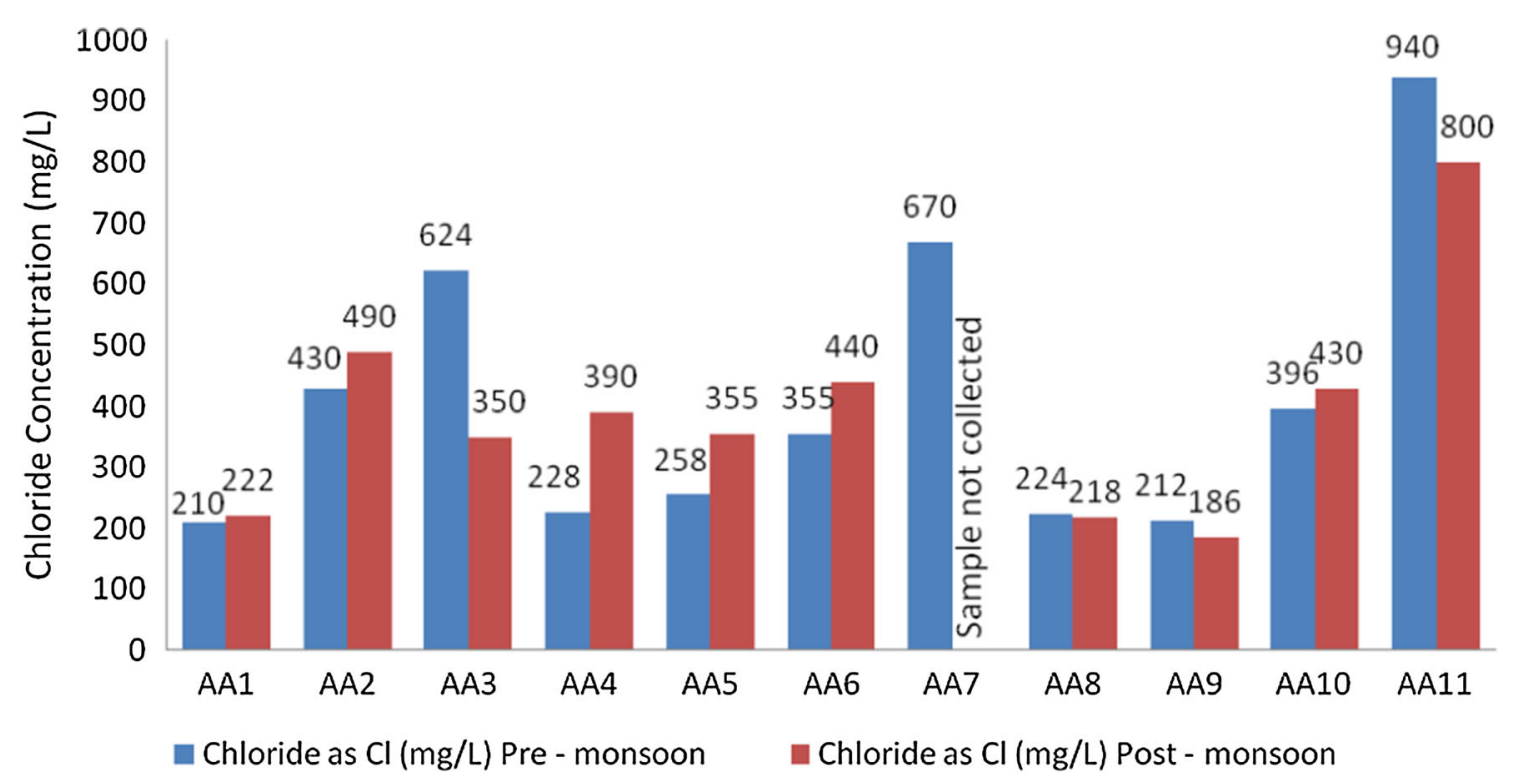

Fig. 10 Chloride concentration in samples BIS limit (1000 mg/L) collected from Ayodhya Kunj

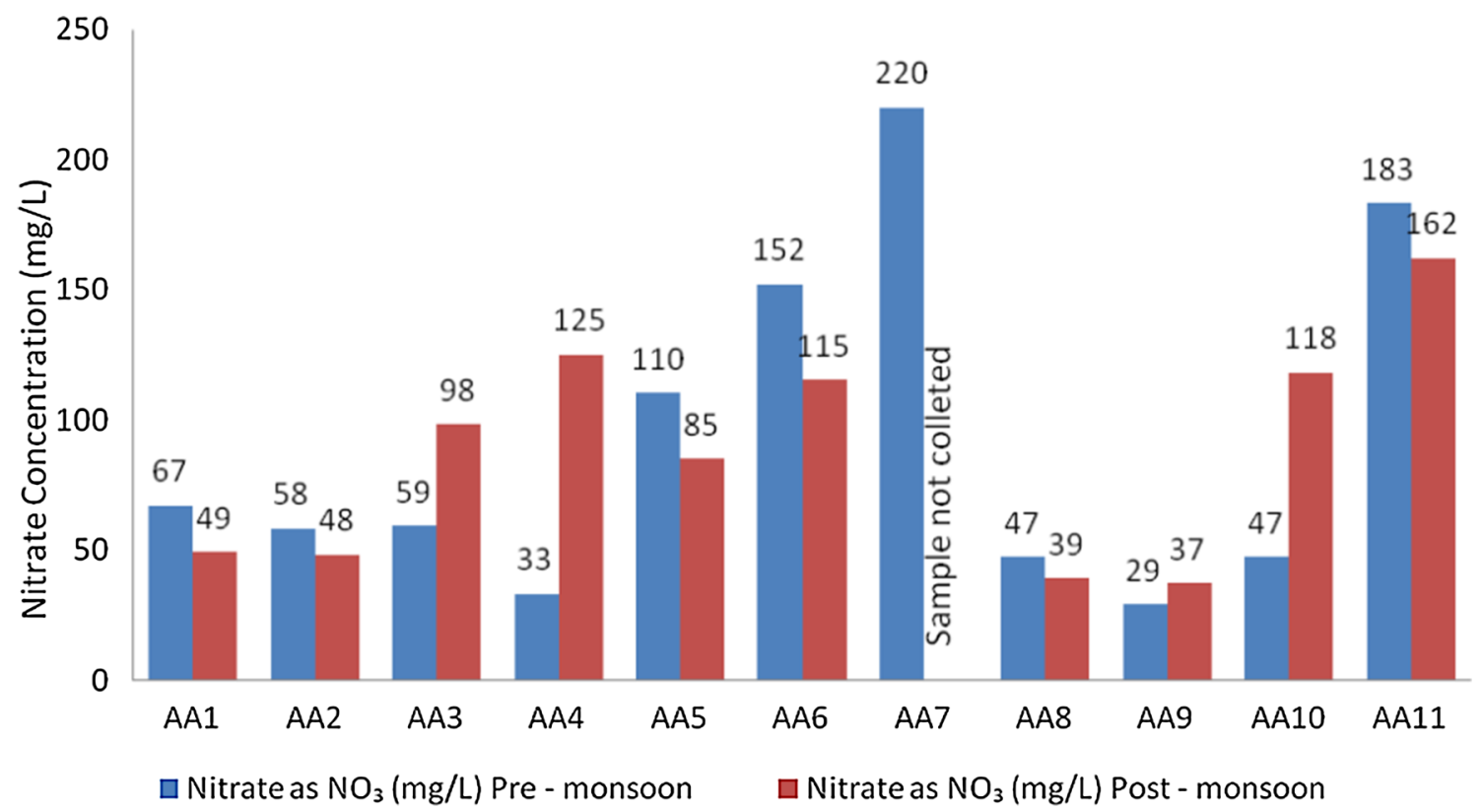

Fig. 11 Nitrate concentration in samples BIS limit (45 mg/L) collected from Ayodhya Kunj

control samples. Every house hold having individual septic tank in this locality and which were located close to the jet pump $(<15 \mathrm{~m})$. The water table in the locality varied in the range 10-30 $\mathrm{m}$ and the distance of the bore well from septic tank about 3-7 m. The TDS varied in the range $265-730 \mathrm{mg} /$ $\mathrm{L}$ in pre-monsoon and $395-900 \mathrm{mg} / \mathrm{L}$ in post-monsoon (Fig. 13). The average concentration of chloride in pre-monsoon was $(80.6 \mathrm{mg} / \mathrm{L})$ and it was more as compared to the post-monsoon concentration $(70.9 \mathrm{mg} / \mathrm{L})$ (Fig. 14). The chloride concentration in all the samples was within the BIS limit $(1000 \mathrm{mg} / \mathrm{L})$. A close look at nitrate concentration revealed that (Fig. 15) the average value of $12 \mathrm{mg} / \mathrm{L}$ in pre- monsoon is almost similar to post-monsoon average value $(12.1 \mathrm{mg} / \mathrm{L})$. All the samples have concentration levels of TDS, chloride and nitrate within the permissible limit of BIS (1991) and WHO (1993) in both seasons. Bacterial count of faecal coliform varied in the range ND-80 CFU/100 mL in pre-monsoon which is greater than ND-25 CFU/100 mL in post-monsoon (Fig. 16). Sample ASP1, ASP5 and ASP7 show higher count of faecal coliforms in pre-monsoon. ASP3 is free from faecal coliforms in both the season. Overall, samples ASP8, ASP9 and ASP10 show minimal contamination owing to the fact that no On-site activities exist near these locations. 


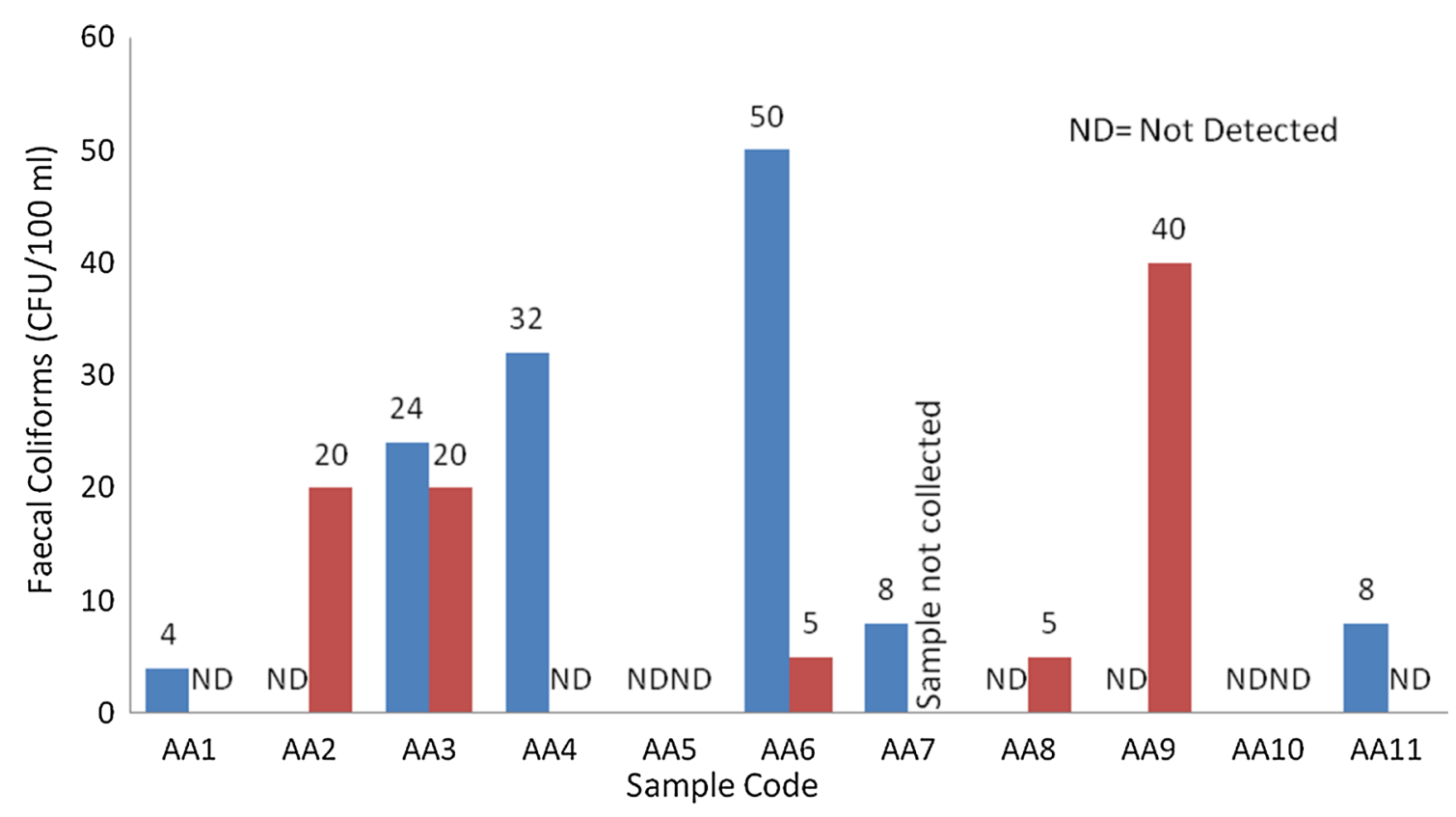

— Faecal Coliforms (CFU/100 ml) Pre-monsoon Faecal Coliforms (CFU/100 ml) Post-monsoon

Fig. 12 Faecal coliforms in samples collected from Ayodhya Kunj

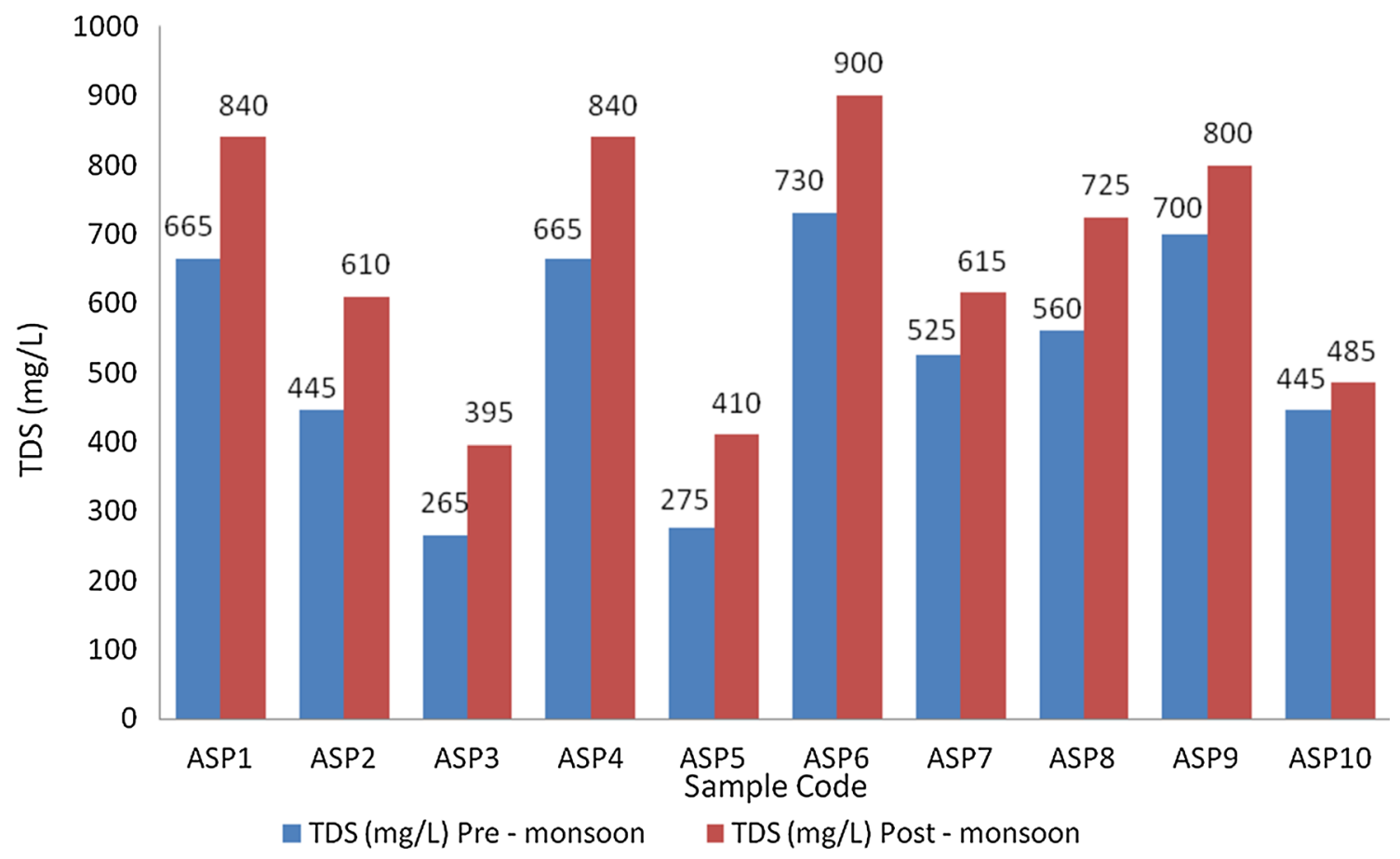

Fig. 13 TDS in samples BIS limit (2000 mg/L) collected from Laxmi Nagar

\section{Questionnaire survey}

A systematic questionnaire survey was undertaken at the time of sampling and the people dependent on the sources were asked about the prevalence of water-borne disease. The localities, Laxmi Nagar and Pandav Nagar, have sparse density of houses and better amenities; hence, the respondents have so far not encountered chronic water diseases. The respondents complained of jaundice during the period (1996-2000) in Ayodhya Kunj locality. It is likely that the outbreak of jaundice may be linked to the presence of coliforms as well as the poor sewerage in 


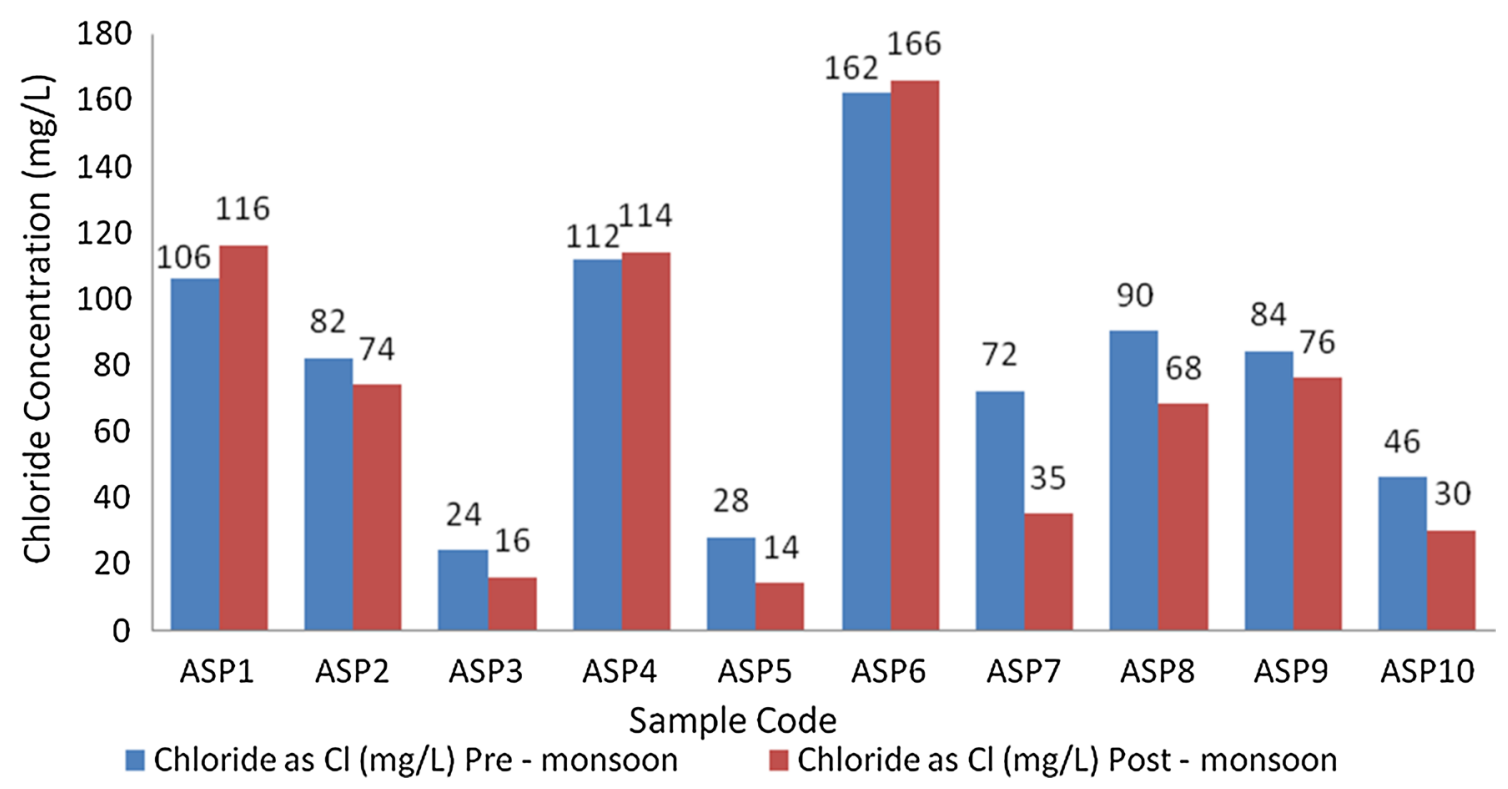

Fig. 14 Chloride concentration in samples BIS limit (1000 mg/L) collected from Laxmi Nagar

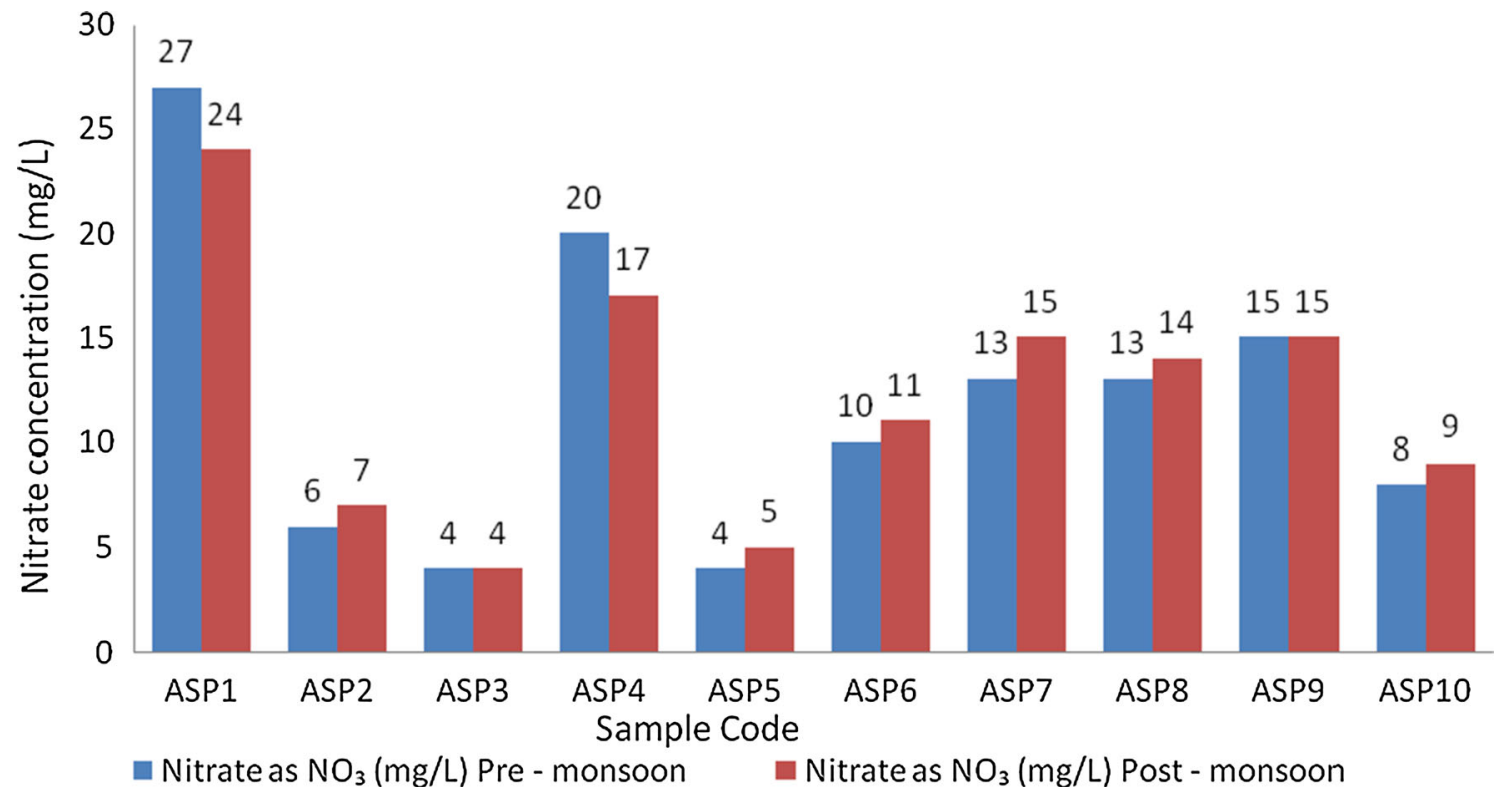

Fig. 15 Nitrate concentration in samples BIS limit (45 mg/L) collected from Laxmi Nagar

Ayodhya Kunj as compared to Laxmi Nagar and Pandav Nagar where there is better sewerage. The overall sanitation in Pandav Nagar and Laxmi Nagar also looks better.

\section{Conclusion}

The sites at Agra are characterized by alluvial setting. It appears that the septic tanks have not able to contain the contamination by coliform. However, they do indicate significant concentration of nitrate and faecal coliform. The nitrate concentration exceeds the BIS permissible limit (45 mg/L) and hence the situation is alarming for the two localities, namely, Pandav Nagar and Ayodhya Kunj. It is observed that the densely populated locality of Ayodhya Kunj recorded high concentration of nitrate (range 29-220 mg/L) as compared to Pandav Nagar and Laxmi Nagar which are relatively less populated. The samples are contaminated by faecal coliform in both pre-monsoon and post-monsoon. As the soil type is mostly coarse sand, in which the movement of contaminants will be faster as compared to fine sand, the aquifer is affected more due to 


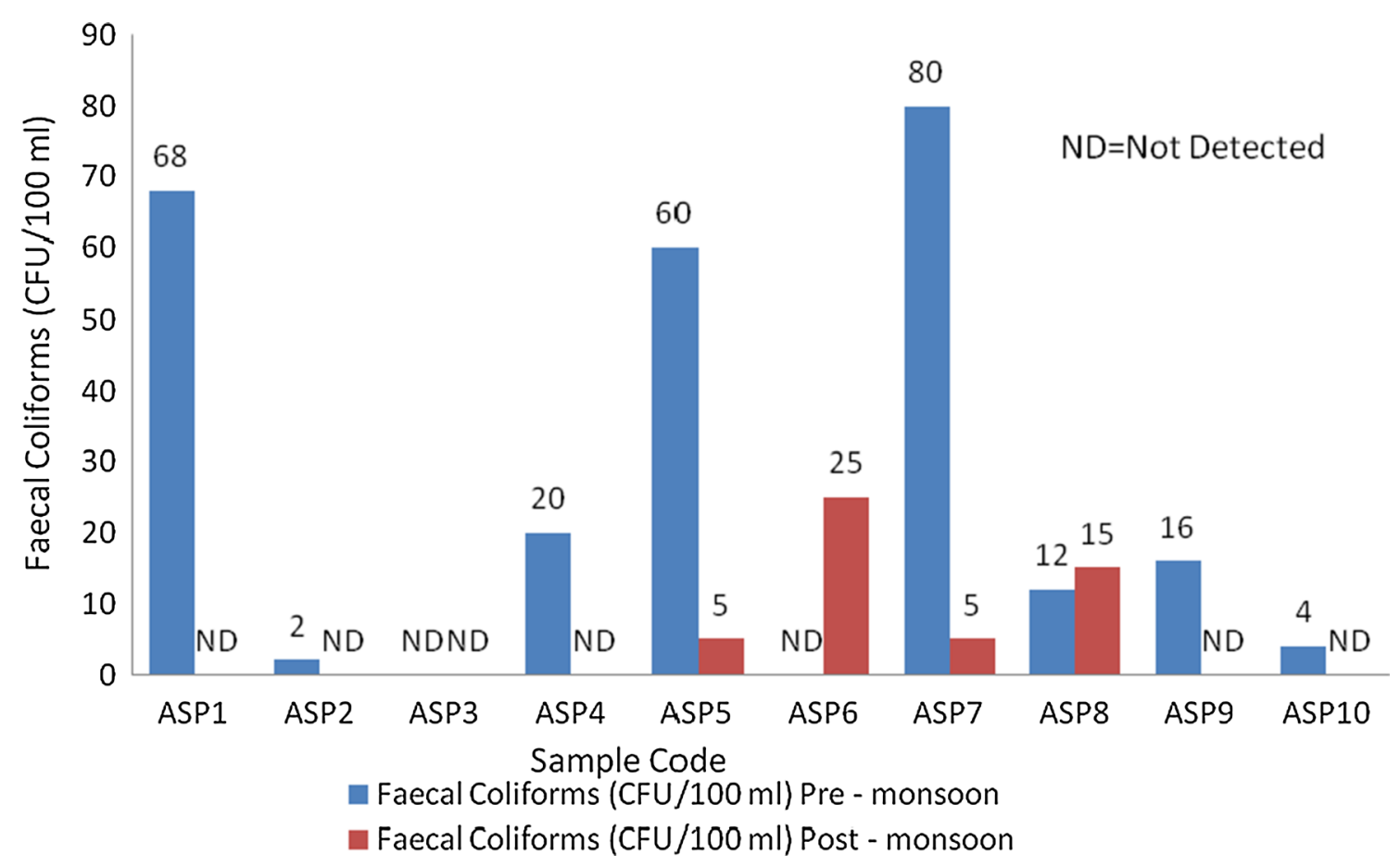

Fig. 16 Faecal coliforms in samples collected from Laxmi Nagar

the coarse sand structure. The findings are contrary to those from other alluvial areas like Lucknow (Jangam et al. 2015) and Kolkata (Pujari et al. 2012). As per the BIS guidelines, faecal coliform should be absent to render the water potable. Hence, there is health risk due to presence of faecal coliform.

\section{Recommendations}

- A systematic hydrogeological mapping of the aquifers in the study area should be undertaken before implementation of On-site sanitation system. If multiple aquifers are present, the groundwater from the deeper aquifer should be tapped for drinking as compared to the shallow aquifer. If off-site sanitation cannot be provided, best design for the On-site sanitation should be ensured.

- Mandatory monitoring of faecal coliforms should be carried out monthly and critical parameter like nitrate should be carried out at least in pre-monsoon and postmonsoon season.

- It is desired that the people drinking the faecal coliform contaminated sources should boil the water before it is used for drinking.

Acknowledgements The authors express gratitude to CPHEEOWHO for sponsoring the research study. The authors thank Director, CSIR-NEERI, P. R. Pujari (Project Leader) and Pawan Labhasetwar
(Head of Division), Water Technology and Management Division, CSIR-NEERI, Nagpur, for their support and encouragement during entire period of the study.

Open Access This article is distributed under the terms of the Creative Commons Attribution 4.0 International License (http:// creativecommons.org/licenses/by/4.0/), which permits unrestricted use, distribution, and reproduction in any medium, provided you give appropriate credit to the original author(s) and the source, provide a link to the Creative Commons license, and indicate if changes were made.

\section{References}

Agra Official Website (agra.nic.in)

APHA (1998) Standard methods for the examination of water and wastewater, 20th edn. American Public Health Association, Washington

Banerjee G (2011) Underground pollution travel from leach pits of on-site sanitation facilities: a case study. Clean Technol Environ 13(3):489-497

Bureau of Indian Standards (BIS) (1991) Drinking water standards: IS 10500:1991.

Census 2011 (censusindia.gov.in)

Ground Water Year Book (GWYB) (2014-2015) Central Ground Water Board (CGWB), Uttar Pradesh

Dzwairo B, Hoko Z, Love D, Guzha E (2006) Assessment of the impacts of pit latrines on groundwater quality in rural areas: a case study from Marondera district, Zimbabwe. Phys Chem Earth 31:779-788

Jangam C, Chaturvedi MK, Pujari PR, Ramya Sanam S, Padmakar C, Labhasetwar PK (2015) Impact assessment of on-site sanitation system on groundwater quality in the alluvial settings: a case

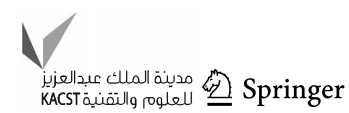


study from Lucknow in North India. Environ Monit Assess 187:614

Lawrence AR, Macdonald DMJ, Howard AG, Barret MH, Pedley S, Ahmed KM et al (2001) Guidelines for assessing the risk of groundwater from on-site sanitation. Commissioned report (CR/ 01/142) of British Geological Survey, Nottingham (Keyworth, Nottingham NG12 5GG) and Edinburgh (Murchison House, West Mains Road, Edinburgh EH9 3LA)

Lu Y, Tang C, Chen J, Sakura Y (2008) Impact of septic tank systems on local groundwater quality and water supply in the Pearl River Delta, China: case study. Hydrol Process 22:443-450

NEERI (2005) Impact of on-site sanitation systems on quality of groundwater and surface water sources submitted to CPHEEOWHO. New Delhi
Pujari PR, Nanoti Madan, Nitnaware Vaishali C, Khare Leena A, Thacker NP, Kelkar PS (2007) Effect of on-site sanitation on groundwater contamination in a basaltic environment-a case study from India. Environ Monit Assess 134:271-278

P. R. Pujari, C. Padmakar, P. K. Labhasetwar, P. Mahore, A. K. Ganguly (2012) Assessment of the impact of on-site sanitation systems on groundwater pollution in two diverse geological settings-a case study from India. Environ Monit Assess 184(1):251-263

WHO (1993) Guidelines for drinking water quality, recommendations, vol 1, 2nd edn. World Health Organization, Geneva 